\title{
AGROGSTA
}

Journal Agroista. Vol. 5 ,No.2 November 2021

Journal home page: https://jurnal.instiperjogia.ac.id/index.php/AGl

ISSN : $2597-3835$ e-ISSN : $2684-7019$

\section{RESPON PERTUMBUHAN BIBIT KELAPA SAWIT (Elaeis guineensis Jacq.) DI PRE NURSERY TERHADAP KOMPOSISI BAHAN ORGANIK DAN KONSENTRASI PLANT GROWTH PROMOTING RHIZOBACTERIA}

\author{
Ety Rosa Setyawati ${ }^{*}$, Gilang Witjaksono² \\ ${ }^{1}$ Department of Agrotechnology, Faculty of Agriculture, Stiper Agricultural Institute, \\ Yogyakarta, Indonesia
}

${ }^{2}$ Degree Program of Agricultural Science, Stiper Agricultural Institute Yogyakarta, Indonesia Email Korespondensi: ettyrosa@instiperjogja.ac.id

\begin{abstract}
The objective of this study was to know the effect of plant growth promoting rhizobacteria on organic matter different dosages. This study was conducted in Educational and Research Garden of Instiper at Kalikuning Village, Depok Residence, Sleman, Yogyakarta Province, Indonesia. This study was started at June 18th 2020 until January 2nd 2021. Completely Randomized Design (CRD) was used in this two factorials experiment. The first factor was Plant Growth Promoting Rhizobacteria (PGPR) on 4 levels, those were 0 (control), 5,10 and $15 \mathrm{ml} / \mathrm{l}$. The second factor was regusol and organic matter composition. Those were regusol and organic matter composition (1:0), (1:1), and (1:2). Anova was used to analyze if there were any significantly different and then to be continued with Duncan Multiple Range Test at $5 \%$ level. The results of this study showed there were interaction significantly between PGPR consentration with organic matter composition on crown wet weight and crown dry weight. The most efficient was found on $9 \mathrm{ml} / \mathrm{I}$ PGPR and 1:1 composition of regusol and organic matter.
\end{abstract}

\section{PENDAHULUAN}

Tanaman kelapa sawit (Elaeis guineensis Jacq.) merupakan tanaman penghasil minyak nabati yang hingga saat ini diakui paling produktif dan ekonomis dibanding minyak nabati lain. Selain itu kelapa sawit bisa digunakan sebagai bahan baku mulai dari industry makanan, hingga industry kimia dan bioenergy. Kayu sawit tua bias digunakan untuk bahan bangunan, sterefoam dan kantong plastic yang ramah lingkungan. Selain itu limbah sawit bias digunakan sebagai pupuk organic.

Menurut GAPKI/Gabungan Pengusaha Kelapa Sawit Indonesia (2021) total produksi minyak sawit Indonesia pada Agustus 2021 mencapai 4,6 juta ton. Jumlah ini naik 4 \% 
disbanding bulan sebelumnya. Konsumsi minyak sawit paling besar yakni untuk pangan sebesar 718 ribu ton, jumlah ini naik 1,41\% dari bulan sebelumnya. Selain itu konsumsi biodiesel di Tanah Air sebesar 569 ribu ton, naik 2,33 \%. Data dari kementrian BUMN luas perkebunan sawit di Indonesia per Juli 20201 seluas 16,3 juta hektar. Namun sebagian besar dari tanamannya sudah kurang produktif karena factor umur dan perlu peremajaan. Hal ini tentu memerlukan ketersediaan bibit yang banyak dan berkualitas.

Keberhasilan penanaman kelapa sawit yang dipelihara selama 25 tahun di lapangan ditentukan dari sifat-sifat bahan-bahan atau bibit yang dipakai. Selama ini untuk pembibitan kelapa sawit masih banyak yang kurang memperhatikan media tanam. Untuk media tanam bibit kelapa sawit dapat digunakan tanah dicampur dengan bahan organik, untuk memperbaiki sifat fisik, kimia, dan biologi tanah. Bahan organic tanah merupakan bahan di dalam atau permukaan tanah yang berasal dari sisa tumbuhan, hewan, dan manusia baik yang telah mengalami dekomposisi lanjut maupun yang sedang mengalami proses dekomposisi. Secara substansi bahan organic tersusun dari humus dan non humus. Bahan organic memegang peranan penting dalam meningkatkan dan mempertahankan kesuburan kimia, fisika dan fisiko kimia yang akan menentukan tingkat produktifitas tanaman dan keberkelanjutan penggunaan lahan untuk pertanian. Selain ramah lingkungan bahan organic murah, mudah didapatkan bahkan bias dibuat sendiri oleh petani.

Bahan organik/pupuk organik memacu dan meningkatkan populasi mikrobia di dalam tanah jauh lebih besar daripada hanya memberikan pupuk kimia (Sutanto, 2002). Bahan organik memacu pertumbuhan dan perkembangan bakteri dan biota tanah. Secara umum bahan organik berguna bagi konservasi lahan kritis yang semakin meluas di Indonesia (Juliani et al, 2017).

Tanah sebagai tempat tanaman untuk berkembang mengandung banyak mikroba yang hidup di dalamnya, beberapa hidup secara berkelompok di sekitar daerah perakaran tanaman dan bersifat menguntungkan untuk pertumbuhan tanaman, simbiose ini secara langsung maupun secara tidak langsung bisa mengurangi penggunaan pupuk kimia.

Kelompok mikroorganisme tanah ini disebut Plant Growth Promoting Rhizobacteria (PGPR). PGPR adalah mikroorganisme tanah yang bersifat menguntungkan bagi tanaman dan hidup di daerah perakaran atau rizhosfer. Aplikasi PGPR dipilih sebagai salah satu metode untuk memperbaiki kesuburan tanah yang mengalami penurunan atau biasa disebut dengan bioremidiasi. Hal itu karena bakteri yang terkandung dalam PGPR ini dapat memfiksasi nitrogen dari udara bebas, bakteri tersebut yaitu Azospirillum, Rhizobium, Azotobacter (Utami et al, 2018). PGPR berpengaruh terhadap tanaman baik secara langsung maupun tidak langsung. Pengaruhnya secara langsung adalah kemampuan menyediakan dan memobilisasi 
penyerapan berbagai macam unsur hara dan mengubah konsentrasi fitohormon pemacu tumbuh. Sementara keuntungan tidak langsungnya adalah kemampuan menekan aktivitas patogen (Kurniawan, 2018).

Berdasarkan uraian tersebut, maka dilakukan penelitian tentang Respon Pertumbuhaan Bibit Kelapa Sawit di Pre Nursery terhadap Pemberian Konsentrasi PGPR dan Dosis.

\section{METODOLOGI}

\section{Waktu dan tempat pelaksanaan}

Penelitian ini dilakukan di KP2 Institut Pertanian STIPER yang terletak di Desa Kalikuning, Kecamatan Depok, Kabupaten Sleman, DIY. dengan ketinggian tempat 118 mdpl. Penelitian ini dilakukan pada 18 Juni 2020 sampai 2 Januari 2021.

\section{Bahan dan alat}

Alat yang digunakan dalam penelitian ini meliputi polybag, cangkul, ayakan, ember, plastik label, gelas plastik, gergaji, meteran, parang, petridish, oven, timbangan analitik, gunting, plastik, smartphone, serta alat tulis berupa pena, pensil, penggaris, penghapus, dan buku. Bahan yang digunakan dalam penelitian ini meliputi, benih kelapa sawit, PGPR (Tanitech), air, insektisida, fungisida, tanah regusol, dan bahan organik (Petroganik).

\section{Rancangan penelitian}

Penelitian merupakan factorial dengan yang disusun dalam rancangan acak lengkap (RAL) yang terdiri dari 2 faktor. Faktor pertama adalah konsentrasi PGPR yang terdiri dari 4 aras, yaitu : $0 \mathrm{ml} / \mathrm{l}, 5 \mathrm{ml} / \mathrm{l}, 10 \mathrm{ml} / \mathrm{l}$ dan $15 \mathrm{ml} / \mathrm{l}$. Faktor kedua adalah komposisi bahan organik yang terdiri dari 3 aras, yaitu : tanah regusol (kontrol), 1:1 (regusol:petroganik) dan 1:2 (regusol:petroganik).

Kombinasi perlakuan yang diperoleh adalah $4 \times 3=12$ kombinasi. Pada setiap kombinasi perlakuan dilakukan 4 ulangan sehingga jumlah bibit yang dibutuhkan sebanyak $12 \times 4=48$ bibit.

\section{Pelaksanaan penelitian}

1. Persiapan lahan

Lahan dibersihkan dari gulma-gulma dan benda-benda asing. Kemudian, dilakukan pembuatan bedengan dan dibuat naungan seluas $6 \mathrm{~m}^{2}$ dengan panjang 3 meter dan lebar 
2 meter yang menghadap ke timur dengan membujur ke utara-selatan dengan ketinggian 2 meter timur dan 1,75 meter barat yang beratap dan dipagari plastik transparan.

2. Persiapan Media tanam

Tanah yang digunakan tanah regusol. Setiap polybag biasanya berisi berat tanah 1,5 kg. Polybag nantinya akan diisi tanah regusol dan bahan organic (petroganik) sesuai perlakuan. Pembuatan media tanam yaitu dengan mengisi polybag tanah regusol dengan bahan organik dengan perbandingan $1: 1$ untuk 16 tanaman, kemudian mencampurkan tanah regusol dengan bahan organik dengan perbandingan $1: 2$ untuk 16 tanaman, dan kontrol menggunakan tanah regusol untuk 16 tanaman, untuk kontrol dengan menggunakan tanah regusol diberi pupuk NPK 2 gram setelah 1 bulan setelah tanam. Kemudian diisikan ke dalam polybag yang berukuran $23 \times 15 \mathrm{~cm}$ (berat media 1,5 kg), selanjutnya disusun di dalam bedengan sesuai dengan layout percobaan dan disiram air hingga menetes di bawah, dan didiamkan 24 jam.

3. Penanaman

Pembuatan lubang tanam dilakukan dengan ibu jari dengan kedalaman $3 \mathrm{~cm}$ kemudian kecambah dimasukan ke dalam lubang tanam dan ditutup dengan tanah dengan memberikan tekanan secara perlahan agar akar (radikula) dan tunas (plumula) tidak patah. Posisi calon tunas (plumula) menghadap ke atas, sedangkan bakal akar (radikula) menghadap ke bawah. Proses penanaman harus dilakukan secara hati-hati.

4. Pemupukan

Pemupukan dilakukan 2 minggu sekali sesuai standar dosis yang telah dianjurkan. Pemupukan hanya di lakukan pada perlakuan kontrol dengan pemberian pupuk NPK (Anorganik) 2 gram diaplikasikan/dibagi 2 kali.

5. Pemeliharaan Tanaman

Apabila ada OPT (Organisme Pengganggu Tanaman) seperti gulma, hama dan penyakit dilakukan penanganan secara manual agar tidak mengganggu pertumbuhan tanaman.

6. Penyiraman

Penyiraman tanaman dilakukan setiap hari yaitu pada pagi hari dan sore hari, masing masing $50 \mathrm{ml}$ pada pagi hari dan $50 \mathrm{ml}$ pada sore hari. Waktu tanaman umur 1 bulan maka penyiraman naik menjadi $75 \mathrm{ml}$ pada pagi hari dan $75 \mathrm{ml}$ pada sore hari, setelah bibit umur 2 bulan maka penyiraman sore hari $150 \mathrm{ml}$. 


\section{HASIL DAN PEMBAHASAN}

Hasil analisis data disajikan pada tabel 1, 2, 3 dan 4 berikut:

Tabel 1. Pengaruh konsentrasi PGPR dan komposisi Bahan Organik terhadap berat segar tajuk kelapa sawit di PN.

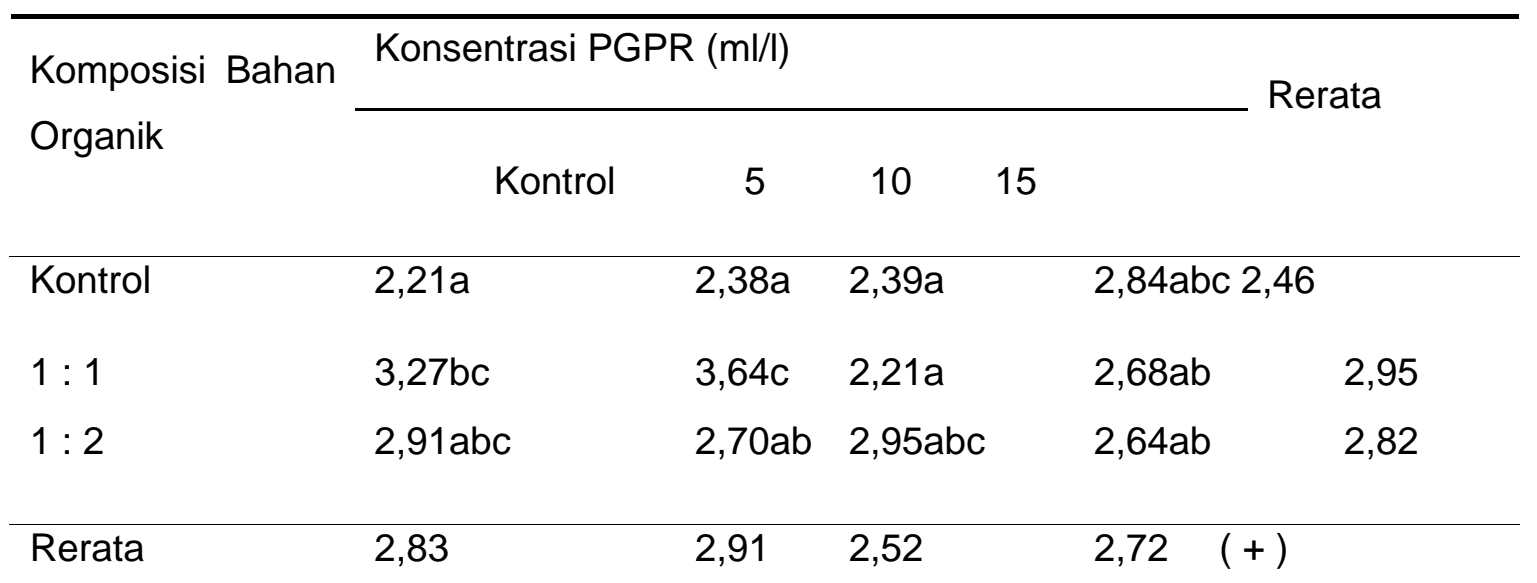

Keterangan: Angka rerata yang diikuti huruf yang sama pada baris yang sama menunjukkan tidak berbeda nyata berdasarkan DMRT pada jenjang nyata $5 \%$.

Anova menunjukkan terdapat interaksi nyata antara bahan konsentrasi PGPR dengan komposisi bahan organik. Konsentrasi PGPR $5 \mathrm{ml} / \mathrm{l}$ dan komposisi bahan organik 1:1 menghasilkan berat segar tajuk tertinggi. Perlakuan konsentrasi PGPR dan komposisi bahan organik yang menunjukkan hasil interaksi ini diduga karena kandungan bahan organik yang terkandung digunakan oleh bakteri PGPR sebagai sumber energi yang berguna untuk melakukan aktivitas di dalam tanah, sehingga unsur - unsur hara menjadi cepat tersedia untuk tanaman. Hal ini juga mempengaruhi bakteri yang terkandung dalam PGPR menambat $\mathrm{N}_{2}$ dari udara sehingga unsur Nitrogen tersedia di tanah. Menurut Hidayat et al (2013) untuk mendukung kehidupan mikroorganisme di dalam tanah kondisi lingkungan harus mendukung, tanah yang mengandung banyak bahan organik akan menjadi sumber energi bagi mikroorganisme utnuk melakukan aktivitasnya di dalam tanah.

Tabel 2. Pengaruh konsentrasi PGPR dan Komposisi Bahan Organik terhadap berat kering tajuk kelapa sawit di PN

\begin{tabular}{lllll}
\hline Komposisi Bahan & \multicolumn{4}{l}{ Konsentrasi PGPR $(\mathrm{ml} / \mathrm{l})$} \\
\cline { 2 - 5 } Organik & Kontrol & 5 & 10 & 15
\end{tabular} Rerata




\begin{tabular}{llllll}
\hline Kontrol & $0,43 a$ & $0,49 a b$ & $0,48 a b$ & $0,56 a b$ & 0,49 \\
$1: 1$ & $0,64 b c$ & $0,73 c$ & $0,44 a$ & $0,59 a b c$ & 0,60 \\
$1: 2$ & $0,58 a b c$ & $0,53 a b$ & $0,56 a b c$ & $0,50 a b$ & 0,54 \\
& & & & & \\
\hline Rerata & 0,55 & 0,58 & 0,49 & 0,55 & $(+)$
\end{tabular}

Keterangan: Angka rerata yang diikuti huruf yang sama pada baris yang sama tidak berbeda nyata berdasarkan DMRT pada jenjang nyata $5 \%$.

Hasil analisis menunjukkan terdapat interaksi nyata antara komposisi bahan organik dengan konsentrasi PGPR. Konsentrasi PGPR $5 \mathrm{ml} / \mathrm{l}$ dan komposisi bahan organik 1:1 menghasilkan berat kering tajuk tertinggi. Perlakuan konsentrasi PGPR dan dosis bahan organik yang menunjukkan hasil interaksi ini diduga karena kandungan bahan organik yang terkandung digunakan oleh bakteri PGPR untuk sumber energi yang berguna untuk melakukan aktivitas di dalam tanah, sehingga unsur hara cepat tersedia bagi tanaman. Hal ini juga mempengaruhi bakteri yang terkandung dalam PGPR menambat N2 dari udara sehingga unsur Nitrogen tersedia di tanah. Menurut Hidayat et al (2013) mikroorganisme yang hidup di dalam tanah memerlukan kondisi lingkungan yang mendukung untuk hidup. Lingkungan yang terdapat unsur bahan organik menjadi tempat yang ideal untuk kehidupan mikroorganisme tanah. Tanah yang terdapat banyak bahan organik akan menjadi sumber energi bagi mikroorganisme tanah untuk menjalankan kehidupannya sehingga dapat membuat produktivitas suatu tanaman meningkat. Selain itu pemberian PGPR dapat juga bermanfaat bagi kesuburan unsur hara yang terkandung di dalam tanah. Hal ini sejalan dengan pendapat Christy et al (2018) bahwa pengaplikasian PGPR dapat meningkatkan jumlah bakteri yang memfiksasi unsur nitrogen dari udara, dan menjadikan unsur nitrogen tersedia bagi tanaman. Bakteri yang terkandung dalam PGPR ada yang berfungsi memfiksasi nitrogen dari udara seperti Rhizobium sp., Azotobacter sp., yang memiliki kemampuan memfiksasi N2 di udara. N2 di udara presentasenya sampai $78 \%$, tetapi nitrogen yang diambil dari udara tersebut belum bisa dipergunakan oleh secara langsung oleh tanaman, kecuali nitrogen sudah menjadi bentuk nitrat yang siap diserap oleh tanaman.

Tabel 3. Pengaruh perlakuan konsentrasi PGPR terhadap pertumbuhan bibit kelapa sawit di PN.

\begin{tabular}{|c|c|c|c|c|}
\hline \multirow[t]{2}{*}{ Parameter Perumbuhan } & \multicolumn{4}{|c|}{ Konsentrasi PGPR (ml/l) } \\
\hline & Kontrol & 5 & 10 & 15 \\
\hline Tinggi bibit $(\mathrm{cm})$ & $23,96 p$ & $24,65 p$ & $22,07 p$ & $24,80 p$ \\
\hline
\end{tabular}




\begin{tabular}{lllll}
\cline { 2 - 4 } Jumlah daun (helai) & $3,83 p$ & $4,00 p$ & $3,92 p$ & $3,92 p$ \\
\cline { 2 - 4 } Panjang akar $(\mathrm{cm})$ & $20,05 \mathrm{p}$ & $21,05 \mathrm{p}$ & $20,00 \mathrm{p}$ & $17,89 \mathrm{p}$ \\
Berat segar akar $(\mathrm{g})$ & $0,90 \mathrm{p}$ & $0,77 \mathrm{p}$ & $0,80 \mathrm{p}$ & $1,04 \mathrm{p}$ \\
\cline { 2 - 4 } Berat kering akar $(\mathrm{g})$ & $0,16 \mathrm{p}$ & $0,16 \mathrm{p}$ & $0,15 \mathrm{p}$ & $0,18 \mathrm{p}$ \\
Berat kering tanaman $(\mathrm{g})$ & $0,71 \mathrm{p}$ & $0,74 \mathrm{p}$ & $0,64 \mathrm{p}$ & $0,73 \mathrm{p}$ \\
\hline
\end{tabular}

Keterangan: Angka rerata yang diikuti huruf yang sama pada baris yang sama tidak berbeda nyata berdasarkan DMRT pada jenjang nyata $5 \%$.

Hasil analisis menunjukkan bahwa pemberian Plant Growth Promoting Rhizobacteria (PGPR) dengan dosis $0 \mathrm{ml} / \mathrm{l}$ (kontrol), $5 \mathrm{ml} / \mathrm{l}, 10 \mathrm{ml} / \mathrm{l}$, dan $15 \mathrm{ml} / \mathrm{l}$ tidak berpengaruh nyata terhadap parameter tinggi bibit, jumlah daun, panjang akar, berat segar akar, berat kering akar, dan berat kering tanaman. Hal ini diduga dalam aplikasi dosis PGPR yang diberikan kepada bibit kelapa sawit kurang banyak dan tidak dilakukan perendaman kecambah kelapa sawit. Menurut Nini (2012) fungsi PGPR adalah meningkatkan pertumbuhan tanaman yakni sebagai pemacu atau perangsang pertumbuhan, sebagai penyedia hara (biofertilizer) dengan menambat N2 dari udara, dan sebagai perlindungan terhadap patogen yang ada di dalam tanah, yakni dengan cara mengeluarkan atau menghasilkan senyawa yang bersifat anti patogen. Maka dari itu konsentrasi PGPR pada bibit kelapa sawit ini lebih mengarah pada fungsi melindungi tanaman dari penyakit.

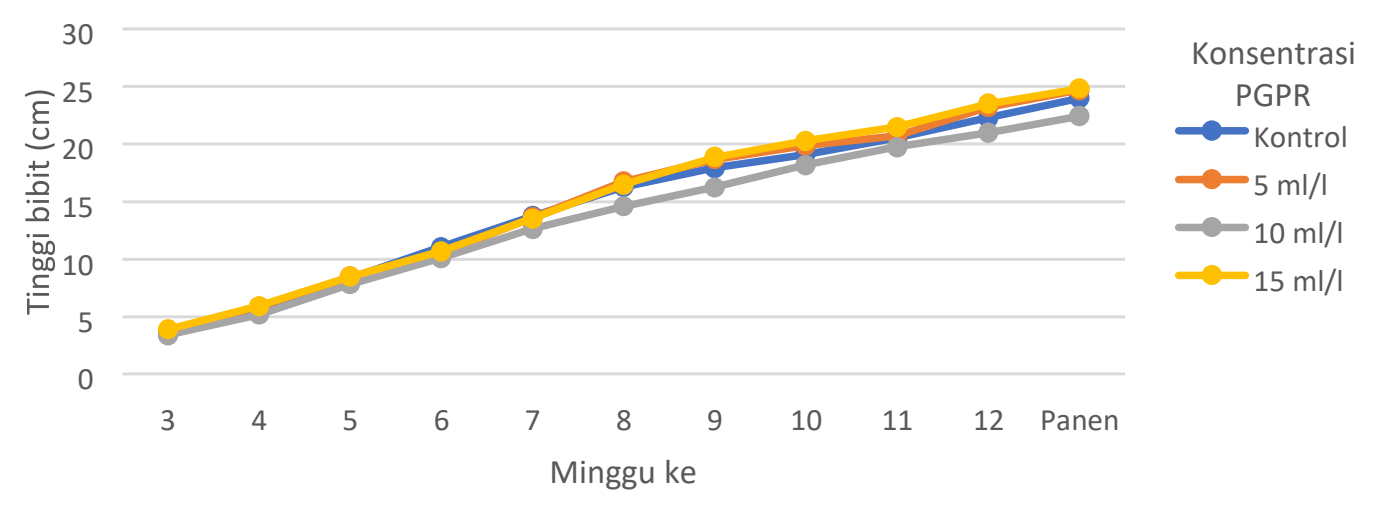

Gambar 1. Pertumbuhan tinggi bibit kelapa sawit setiap minggu berdasarkan Konsentrasi PGPR

Tabel 4. Pengaruh perlakuan Komposisi Bahan Organik terhadap pertumbuhan bibit kelapa sawit di PN

Parameter Perumbuhan Komposisi Bahan Organik 


\begin{tabular}{llll} 
& Kontrol & $1: 1$ & $1: 2$ \\
\hline Tinggi bibit (cm) & $21,96 \mathrm{a}$ & $25,35 \mathrm{~b}$ & $24,31 \mathrm{ab}$ \\
Jumlah daun (helai) & $3,88 \mathrm{a}$ & $3,88 \mathrm{a}$ & $4,00 \mathrm{a}$ \\
Panjang akar $(\mathrm{cm})$ & $20,97 \mathrm{a}$ & $20,46 \mathrm{a}$ & $17,81 \mathrm{a}$ \\
Berat segar akar $(\mathrm{g})$ & $0,93 \mathrm{a}$ & $0,87 \mathrm{a}$ & $0,82 \mathrm{a}$ \\
Berat kering akar $(\mathrm{g})$ & $0,19 \mathrm{a}$ & $0,16 \mathrm{a}$ & $0,14 \mathrm{a}$ \\
Berat kering tanaman $(\mathrm{g})$ & $0,68 \mathrm{a}$ & $0,76 \mathrm{a}$ & $0,69 \mathrm{a}$
\end{tabular}

Keterangan: Angka rerata yang diikuti huruf yang sama pada baris yang sama tidak berbeda nyata berdasarkan DMRT pada jenjang nyata $5 \%$.

Hasil analisis pada perlakuan komposisi bahan organik menunjukkan bahwa terdapat pengaruh nyata nyata pada parameter tinggi bibit. Komposisi bahan organik terbaik 1:1 dan 1:2. Diduga perbaikan pada sifat fisik, kimia, biologi tanah serta ketersediaan air dan unsur hara yang meningkat memudahkan perkembangan akar sehingga dapat berpengaruh nyata pada tinggi tanaman. Venus et al (2018) bahan organik mempunyai peran penting pada perbaikan sifat fisik tanah, yakni pada pembentukan agregat tanah, daya simpan air dalam tanah, dan meningkatkan pori meso dan pori mikro tanah. Begitu pula tanah yang mengandung bahan organik yang cukup akan membuat struktur tanah menjadi remah. Hal itu juga sejalan dengan pendapat Intan et al (2013) bahan organik menjadi salah satu sumber koloid organik yang memiliki segudang manfaat, yakni dapat menyediakan unsur hara mikro dan juga unsur hara makro, dapat memfiksasi unsur mikro logam sehingga menjadi senyawa khelat, meningkatkan daya simpan air, meningkatkan KPK di dalam tanah, dan menjadi sumber energi utama untuk kehidupan mikroorganisme di dalam tanah serta bersifat ramah lingkungan.

Tanah jenis regusol yang punyusun mayoritasnya adalah fraksi pasir yang mempunyai unsur hara yang rendah, kapasitas menahan air rendah, serta mempunyai KPK tanah yang rendah juga. Venus et al (2018) menjelaskan juga bahwa tanah regusol mayoritas fraksi penyusunnya adalah pasiran, hal tersebut membuat tanah regusol mempunyai aerasi tanah yang baik. Tetapi pada tanah regusol mempunyai kelemahan daya simpan air sangat buruk, karena didominasi oleh pori makro. Hasil analisis pada perlakuan komposisi bahan organic pada parameter jumlah daun, panjang akar, berat segar akar, berat kering akar, dan berat kering tanaman menunjukkan tidak terdapat pengaruh nyata. Hal ini diduga kandungan unsur $\mathrm{N}, \mathrm{P}, \mathrm{K}$ dalam tanah regusol dan bahan organik yang digunakan dalam penelitian rendah. Hal itu dibuktikan dengan hasil analisis tanah regusol dan bahan organik yang dipakai, kandungan 
unsur hara $\mathrm{N}, \mathrm{P}, \mathrm{K}$ di tanah regusol dibawah $1 \%$, dan kandungan $\mathrm{N}, \mathrm{P}, \mathrm{K}$ di bahan organik dibawah $2 \%$. Kandungan N, P, K yang rendah itulah yang diduga menyebabkan tidak terdapat pengaruh nyata pada perameter jumlah daun, panjang akar, berat segar akar, berat kering akar, dan berat kering tanaman. Secara fisiologis pertumbuhan tanaman kelapa sawit sangat dipengaruhi oleh nutrisi yang diserapnya (Corley dan Tinker, 2003 ; Noggle dan Fritz, 1979).

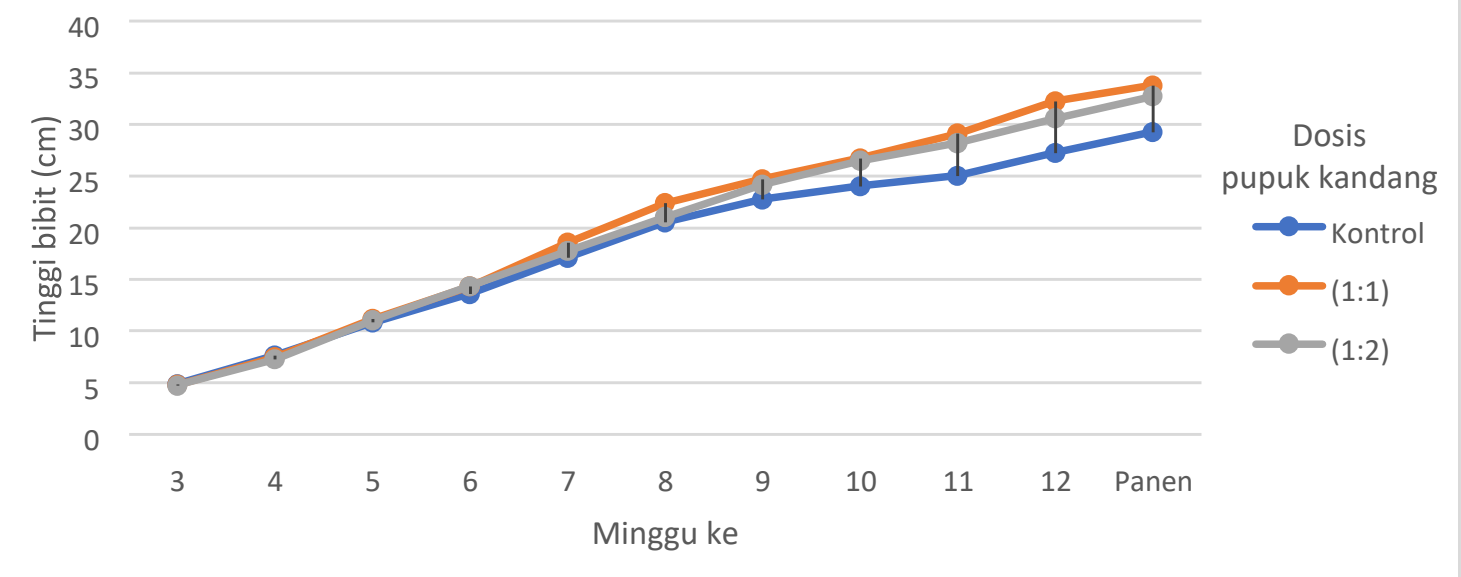

Gambar 2. Pertumbuhan tinggi bibit kelapa sawit setiap minggu berdasarkan komposisi bahan organik.

\section{KESIMPULAN}

Kesimpulan yang dapat diambil dari penelitian adalah :

1. Terdapat interaksi antara konsentrasi Plant Growth Promoting Rhizobacteria dan komposisi bahan organik pada pertumbuhan bibit kelapa sawit di PN, pada parameter berat segar tajuk dan berat kering tajuk.

2. Pemberian konsentrasi PGPR $0 \mathrm{ml} / \mathrm{l}$ pada komposisi bahan organik 1:1 paling efisien terhadap pertumbuhan bibit kelapa sawit di PN.

3. Perlakuan komposisi bahan organik tidak mempengaruhi parameter jumlah daun, panjang akar, berat segar akar, berat kering akar, dan berat kering tanaman. Karena tanah regosol dan bahan organik kandungan $\mathrm{N}, \mathrm{P}, \mathrm{K}$ rendah

\section{DAFTAR PUSTAKA}

Christy N. C., Y. Nuraini., A. G. Pratomo. 2018. Potensi Pemanfaatan Plant Growth Promoting Rhizobacteria (Pgpr) dan Berbagai Media Tanam Terhadap Populasi Mikroba Tanah 
Serta Pertumbuhan dan Produksi Kentang. Jurnal Tanah dan Sumberdaya Lahan 5 (2): 887-899.

Corley, R.H.V. and P.B. Tinker. 2003. The Oil Palm. 4th edition. Backwell Publishing Inc . MA USA.

Hidayat. C., Dedeh. H,. Arief, Nurbity.A.. Sauman.J. 2013. Inokulasi Fungsi Mikoroza Arnuskula dan mycorrhiza helper bacteria pada Andisol yang Diberi Bahan Organik utuk Meningkatkan Stabilitas Agregat Tanah, Serapan N dan P dan Hasil Taaman Kentang. Indonesian Journal of Applied Science 3(2): 26-41.

Intan N., M. M. M. Damanik., G. Sitanggang. 2013. Ketersediaan Nitrogen Pada Tiga Jenis Tanah Akibat Pemberian Tiga Bahan Organik Dan Serapannya Pada Tanaman Jagung. Jurnal Online Agroekoteknologi 1(3).

Juliani R., R. Simbolon., W.H. Sitanggang., J.B. Aritonang. 2017. Pupuk Organik Enceng Gondok Dari Danau Toba. Jurnal Pengabdian Kepada Masyarakat 23 (1) : 220 - 224.

Kurniawan, Andri. 2018. Pengaruh Konsentrasi Pgpr (Plant Growth Promoting Rhizobacteria) Terhadap Pertumbuhan Semai Sengon (Paraserianthes falcataria. L). JAGROS 3 (1): $21-26$.

Mangoensoekarjo, S \& H. Semangun. 2008. Manajemen Agrobisnis Kelapa Sawit. Gadjah Mada University Press, Yogyakarta.

Nini M.R. 2012. Efek Fitohormon Pgpr Terhadap Pertumbuhan Tanaman Jagung (Zea mays). Jurnal Agribisnis dan Pengembangan Wilayah 3(2): 27 - 35.

Noggle, G. R. and G.J. Fritz. 1979. Introductory Plant Physiology. Prentice Hall of India, New Delhi.

Perdana J.F., Murniati., \& E.Ariani. 2014. Pemanfaatan Cendawan Mikoriza Arbuskular (CMA) Untuk Pertumbuhan dan Perkembangan Bibit Kelapa Sawit (Elaeis gueneensis Jacq.) di Pembibitan Awal. Jom Faperta 1(2).

Sunarko. 2014.Budi Daya Kelapa Sawit di Berbagai Jenis Lahan. PT Agromedia Pustaka, Jakarta.

Susetya, Darma. 2014. Panduan Lengkap Membuat Pupuk Organik. Pustaka Baru Press, Yogyakarta.

Sutanto, Rachman. 2002. Penerapan Pertanian Organik. Kanisius. Yogyakarta.

Utami A.P., D. Agustiyani., E. Handayanto. 2018. Pengaruh Pgpr( Plant growth promoting rhizobacteria ), Kapur, Dan Kompos Pada Tanaman Kedelai Di Ultisol Cibinong, Bogor. Jurnal Tanah dan Sumberdaya Lahan 5 (1): 629 - 635.

Venus N., R. Soplanit., A. Siregar. 2018. Efisiensi Pemberian Air dan Kompos Terhadap Mineralisasi NPK Pada Tanah Regosol. J. Budidaya Pertanian 14(2): 105-112. 